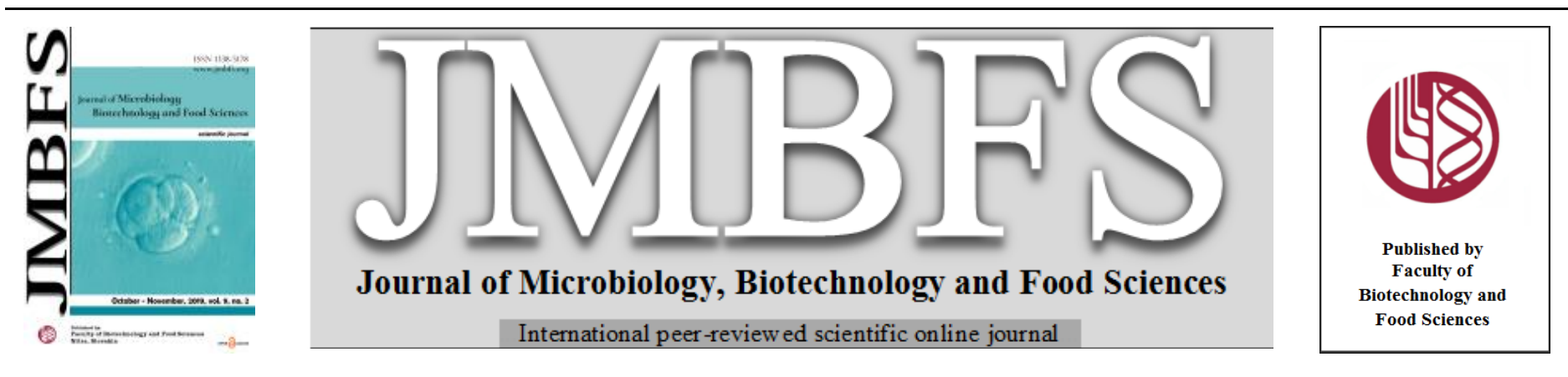

\title{
EXPRESSION, PURIFICATION, AND CHARACTERIZATION OF RECOMBINANT V, THE NEWCASTLE DISEASE VIRUS NON-STRUCTURAL PROTEIN
}

\author{
Amira Ahmed ${ }^{1,2 *}$ and Waleed Osman ${ }^{3}$
}

\section{$\operatorname{Address}(e s)$ :}

${ }^{1}$ Department of Applied Veterinary Sciences, United Graduate School of Veterinary Sciences, Gifu University, Gifu 501-1193, Japan.

${ }^{2}$ Department of Poultry and Rabbit Medicine, Faculty of Veterinary Medicine, Suez Canal University, Ismailia, Egypt.

${ }^{3}$ Medical Sciences Division, United Graduate School of Drug Discovery and Medical Information Sciences, Gifu University, 1-1 Yanagido, Gifu 501-1193, Japan.

*Corresponding author: amira abdelaziz@ vet.suez.edu.eg

doi: 10.15414/jmbfs.2020.9.4.705-707

\section{ARTICLE INFO}

Received 9. 8. 2018

Revised 27. 8. 2019

Accepted 28. 8. 2019

Published 3. 2. 2020

Regular article OPEN $\partial_{\text {ACCESS }}$

\begin{abstract}
Poultry industry facing problems in vaccination of chicken against Newcastle disease virus (NDV) due to the difficulty of differentiating the vaccinated and naturally infected birds. If we could find a key marker that could differentiate, we would bring a great achievement to the industry. NDV genome contains genes for six major structural proteins and two non-structural proteins. The non-structural protein V could be a useful antigen for differentiating chickens infected with NDV from those vaccinated with inactivated whole virus.

We have constructed a recombinant plasmid using the $\mathrm{C}$-terminal region of the non-structural $\mathrm{V}$ protein. Another recombinant plasmid using the C-terminal polypeptide of structural $\mathrm{P}$ protein was developed as a control. We succeeded in expressing the unique C-terminal part of the $\mathrm{V}$ protein in E. coli as a fusion protein with GST (GST-V), $40.8 \mathrm{kDa}$, as well as the C-terminal part of the P protein (GST-P), $55.4 \mathrm{kDa}$. Purified NDV-V and NDV-P proteins had sizes of $14.8 \mathrm{kDa}$ and $29.4 \mathrm{kDa}$, respectively. The antigenicity of recombinant V protein was confirmed with Western blotting assay, which makes the using of this protein as a biological marker prospective.
\end{abstract}

\section{INTRODUCTION}

Newcastle disease (ND) is a highly contagious viral disease affecting over 250 species of birds of all age groups and causes severe economic losses around the world (Ashraf and Shah, 2014). The Newcastle disease virus (NDV) genome contains genes for six major structural proteins: nucleocapsid protein (NP), phosphoprotein $(\mathrm{P})$, matrix protein $(\mathrm{M})$, fusion protein $(\mathrm{F})$, hemagglutininneuraminidase protein $(\mathrm{HN})$, and the large polymerase (L) (Lamb and Parks, 2007). NDV also produces two non-structural proteins, $\mathrm{V}$ and $\mathrm{W}$ proteins, by mRNA editing during transcription of the P gene (Peeters et al., 2004). P mRNA is edited by insertion of one or two additional $\mathrm{G}$ residues into a run of Gs within the conserved editing site, thus generating the $\mathrm{V}$ - and $\mathrm{W}$-encoding mRNAs, respectively (Steward et al., 1993). Due to this unique coding strategy, $\mathrm{P}$ and $\mathrm{V}$ proteins share an amino terminal domain of 134 amino acids and possess unique carboxyl termini of 261 and 105 amino acids, respectively (Liang $\boldsymbol{e t}$ al., 2010). The $\mathrm{V}$ protein plays a direct role in virus replication and in host range restriction, as well as serves as a virulence factor (Park et al., 2003).

In theory, infected chickens will respond to any virus proteins including structural proteins such as $\mathrm{HN}, \mathrm{F}$, and $\mathrm{P}$ and non-structural proteins such as $\mathrm{V}$ and W. However, virions do not incorporate non-structural proteins, only the nucleic acids that encode them. Therefore, chickens that are infected will express nonstructural proteins. In contrast, chickens that are vaccinated with inactivated virus, will not express non-structural proteins. Detection of non-structural proteins is a method for distinguishing infected birds from birds vaccinated with an inactivated virus. For example, Tumpey $\boldsymbol{e t}$ al. (2005) used a non-structural protein of influenza A virus to differentiate between infected and vaccinated chickens. We hypothesized that the $\mathrm{V}$ protein is useful as a diagnostic marker of NDV infection.

In the present study, we selected the C-terminal part of the V-protein as an insert because it is more highly conserved among paramyxoviruses than the $\mathrm{N}$-terminal half and it is unique to the V-protein (Steward $\boldsymbol{e t}$ al., 1993). As a control, we developed another recombinant plasmid using the $\mathrm{C}$-terminal part of the $\mathrm{P}$ protein, which is a structural protein of NDV. The aim of the current study was to express the $\mathrm{V}$ protein in vitro and purify this fusion protein. To our knowledge this is the first study that purified the $\mathrm{V}$ protein and we selected it as a key marker to differentiate the vaccinated and naturally infected birds.

\section{MATERIALS AND METHODS}

The study was done in the microbiology laboratory of the applied veterinary sciences department, Gifu University.

\section{Virus and cell culture}

NDV Hitchner B1 (NDV-HB1) was used in the present study. Chicken embryo fibroblasts (CEFs) were prepared from 10-day-old SPF embryos. NDV-HB1 was inoculated on CEF at m.o.i of $10 \mathrm{EID}_{50} /$ cell. Infected cells were cultivated in $\alpha$ MEM containing $2.5 \mu \mathrm{g} / \mathrm{mL}$ trypsin (Sigma, St. Louis, MO, USA) for three days at $37^{\circ} \mathrm{C}$ (Hernandez, and Brown, 2010).

\section{Reverse transcription-PCR (RT-PCR) analyses}

Total RNA was extracted from infected CEF using TRIZOL (Invitrogen, Carlsbad, CA, USA). One Step RT-PCR assays were done with $4 \mu \mathrm{g}$ of RNA and random primers by using a ReverTra Ace kit (Toyobo, Osaka, Japan) according to the manufacturer's instructions.

\section{PCR and Primers}

An 814-bp fragment corresponding to the 3' end of the P protein coding sequence and a 344-bp fragment corresponding to the $3^{\prime}$ end of the $\mathrm{V}$ protein coding sequence were amplified by PCR. PCR primers for the P protein gene were designed based on the sequence data of GenBank accession no. AF309418. The $\mathrm{V}$ protein primers were designed based on the same sequence of the $\mathrm{P}$ gene of NDV using a plus-one-frame shift. Sequences of the primers are as follows: $P$ forward primer with EcoRI 5'- GCATAATGAATTCGCTAAAAAGGGCCCAT GGTCGAGC -3 , and reverse primer with SalI 5'GCATAATGTCGACTTAGAGCAAGCCGCTTGATTTTC-3', and V forward with EcoRI 5'-GCATAATGAATTCCCCATGG TCGAGCCCCCAAGAG-3' and reverse with SalI 5'- GCATAATGTCGACTTACTTAC TCTTTGGGAAATCCCC-3'. The underlined portions indicate restriction sites added. 


\section{Cloning and sequencing}

PCR products were gel purified using a Nucleospin DNA purification kit (Macherey-Nagel Inc., Easton, PA, USA) and cloned into the pGEM-T-Easy vector (Promega, Madison, WI, USA). The cloned DNA was digested with EcoRI and SalI and inserted into the glutathione S-transferase (GST) fusion protein expression vector pGEX-6P-1 (GE Healthcare). Recombinant clones containing P insert or V insert were named (pGST-P) or (pGST-V), respectively. E. coli DH5 $\alpha$ was transformed with pGST-P or pGST-V DNA. E. coli expressing a recombinant $\mathrm{V}$ or P GST fusion proteins was plated on Luria-Bertani agar and cultivated at $37^{\circ} \mathrm{C}$ overnight (GE Healthcare, 2009). The clone sequences were confirmed by nucleotide sequencing (Doragon Genomics, TAKARA Bio, Mie, Japan).

\section{Protein Expression and Purification}

One colony was inoculated and cultivated in Luria-Bertani broth at $37{ }^{\circ} \mathrm{C}$ supplemented with ampicillin $(100 \mu \mathrm{g} / \mathrm{ml})$ for $6 \mathrm{~h}$. And then recombinant protein expression was induced by adding IPTG at a final concentration of $1 \mathrm{mM}$. The induced culture was incubated at $30{ }^{\circ} \mathrm{C}$ overnight. After centrifugation at $6000 \mathrm{rpm}$ at $4{ }^{\circ} \mathrm{C}$ for $15 \mathrm{~min}$, the pellet was suspended and sonicated in phosphate-buffered saline (PBS) containing 1\% (vol/vol) Triton X-100, lysozyme $(100 \mu \mathrm{g} / \mathrm{ml})$ and DNase $(30 \mathrm{U} / \mathrm{ml})$. The suspension was centrifuged at $12000 \mathrm{rpm}$ for $15 \mathrm{~min}$ at $4{ }^{\circ} \mathrm{C}$. The pellet was kept at $4{ }^{\circ} \mathrm{C}$ for later testing (GE Healthcare, 2009). Expression of the unique $\mathrm{C}$-terminal part of the $\mathrm{V}$ protein in E. coli was confirmed by Western blotting as a fusion protein with GST (GST-V), as well as the C-terminal part of the P protein (GST-P). V (NDV-V) and P (NDV-P) proteins were purified by GSTrap FF column affinity chromatography and PreScission protease (GE Healthcare) according to the manufacturer's instructions.

\section{NDV control serum}

Serum samples were obtained from two 2 months old SPF chicken that has been inoculated intraorally or intraocularly with $30 \mu \mathrm{l} /$ chicken $10^{8.5} \mathrm{EID}_{50}$ live NVDHB1 vaccine (Nipoon Biologicals, Inc, Tokyo, Japan), each received five doses with an interval 2 weeks between them, another two SPF chickens were injected with phosphate buffered saline as a negative control.

\section{SDS-PAGE and Western blotting assays}

Fused or purified protein samples were denatured in SDS sample buffer by boiling for $5 \mathrm{~min}$. Denatured proteins were separated on a $12 \%$ gel and stained with Coomassie brilliant blue R-250 or transferred to a sheet of polyvinylidene difluoride membrane (Immobilon-P; Millipore, Billerica, MA. The blots were blocked with $5 \%(\mathrm{wt} / \mathrm{vol})$ non-fat skim milk, incubated for $1 \mathrm{~h}$ at $37^{\circ} \mathrm{C}$, washed three times in PBS-Tween $20(0.05 \%)$, soaked in NDV infected positive control serum or negative control serum diluted with PBST, incubated for $2 \mathrm{~h}$ at $37^{\circ} \mathrm{C}$, washed three times in PBST, soaked in one of the two following secondary antibodies, anti-GST antibodies conjugated to horseradish peroxidase (GE Healthcare) or goat anti-chicken $\operatorname{IgY}$ conjugated to horseradish peroxidase (Abcam, Tokyo, Japan), incubated for $2 \mathrm{~h}$ at $37^{\circ} \mathrm{C}$, washed three times in PBST, and incubated in ECL Western blotting detection reagents (GE Healthcare) or were developed by using enhanced chemiluminescence diamino-benzidine (DAB; Dojindo). Finally, the membranes were expose X-ray film (Fujifilm, Tokyo, Japan), (Sambrook and Russell, 2001).

\section{RESULTS}

\section{Expression and purification of NDV-P and NDV-V proteins}

An 814-bp fragment corresponding to the $3^{\prime}$ terminal of the $\mathrm{P}$ protein coding sequence and a 344-bp fragment corresponding to the 3 ' terminal of the $\mathrm{V}$ protein coding sequence were amplified (Figure 1) and cloned into the expression vector.

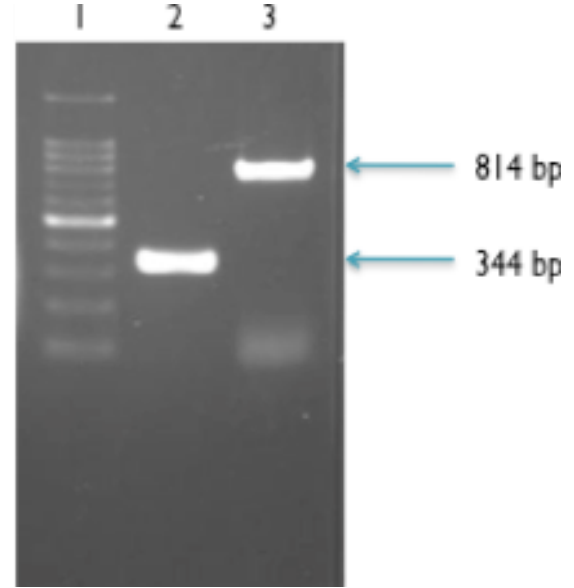

Figure $1 \mathrm{PCR}$ products of the amplified C-terminus of the $\mathrm{p}$ gene, and the Cterminus of the gene encoding the $(\mathrm{V})$ protein. Lane 1: $100 \mathrm{bp}$ marker ladder, Lane 2: $\mathrm{V}$ band, Lane 3: $\mathrm{P}$ band.

We succeeded in expressing the unique C-terminal part of the $\mathrm{V}$ protein in $E$. coli as a fusion protein with GST (GST-V), $40.8 \mathrm{kDa}$, as well as the C-terminal part of the P protein (GST-P), $55.4 \mathrm{kDa}$. (Figure 2).

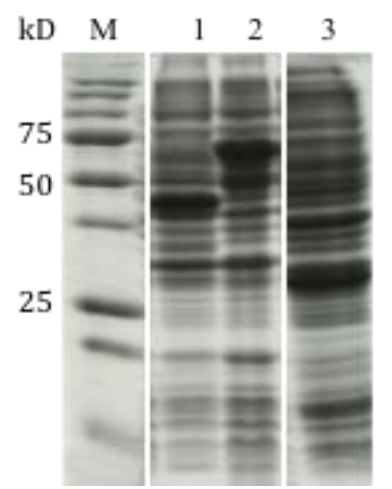

Figure 2 Obtained protein samples were separated on a $12 \%$ polyacrylamide gel using SDS polyacrylamide gel electrophoresis. After electrophoresis, the gel was stained with Coomassie brilliant blue. $\mathrm{M}$, marker; lane 1, fused protein $(\mathrm{GST}+\mathrm{V}, 40.8 \mathrm{kDa})$; lane 2, fused protein $(\mathrm{GST}+\mathrm{P}, 55.4 \mathrm{kDa})$; lane 3, the control plasmid (PGEX-6P1).

Western blotting revealed bands at the expected sizes (Figure 3).

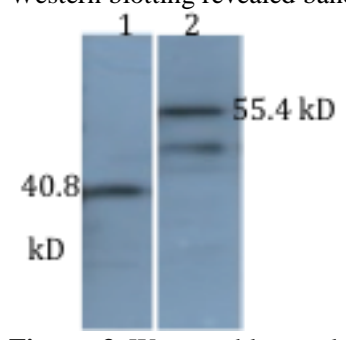

Figure 3 Western blot analysis of fusion proteins. Lane 1: GST+V, lane 2: GST+P.

Purified NDV-V and NDV-P proteins had sizes of $14.8 \mathrm{kDa}$ and $29.4 \mathrm{kDa}$, respectively (Figure 4).

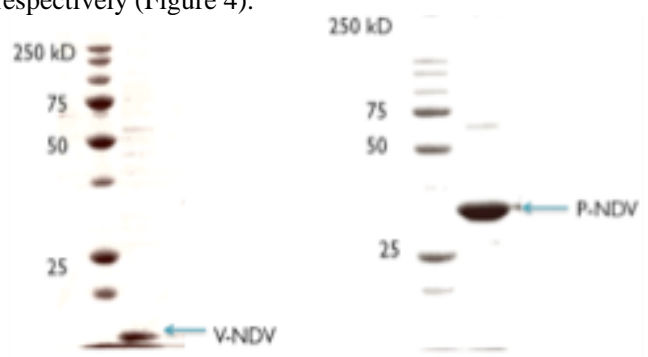

Figure 412\% SDS-PAGE gels demonstrating the purity of recombinant V-NDV (14.8 kDa) and P-NDV (29.4 kDa).

We evaluated the antigenicity of the NDV-V and NDV-P by western blotting with positive control serum against NDV and negative control serum. Antigenicity was confirmed by observation of clear bands at the expected sizes (Figure 5). 


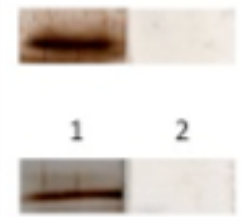

Figure 5 Western blotting analysis of $\mathrm{P}$ and $\mathrm{V}$ proteins. (a) Lane, 1: $\mathrm{V}$ protein was detected by positive serum against NDV (1:100 dilution), Lane, 2: V protein against control negative serum (1:100 dilution). (b) Lane 1, P protein was detected by positive serum against NDV (1:100 dilution), Lane, 2: P protein against control negative serum (1:100 dilution).

\section{DISCUSSION}

The present work describes a simple, efficient method for the expression and purification of the NDV-V. Recombinant protein can be generated in milligram quantities with a simple purification method. In theory, infected chickens will respond to any proteins produced by virus infection including both structural proteins and non-structural proteins. However, chickens immunized by inactivated vaccine will respond to structural proteins but will have little or no response to non-structural proteins (Tumpey et al., 2005), because inactivated vaccine is prepared from infected allantoic fluid, which might include virions and a slight amount of nonstructural proteins. Thus, chickens vaccinated with inactivated vaccine will be regarded as unexposed to $\mathrm{V}$ protein antigen. So that detection of nonstructural proteins is a method for distinguishing infected birds from birds vaccinated with an inactivated virus.

We suggest to using the $\mathrm{V}$ protein as a coating antigen for an indirect ELISA or an indirect Western Blotting that could detect antibodies in poultry infected by NDV and not from poultry vaccinated with the inactivated vaccine., This idea was successfully exploited in the case of influenza A virus by using the nonstructural protein (NS1) as a coating antigen for an indirect ELISA (Tumpey et al., 2005). In the present study, the primary advantage using such diagnostic test is the ability to work with any inactivated vaccine using a single test, to conclude, this method can only be used in birds vaccinated with inactivated vaccine and not in birds vaccinated with live vaccine. Even though the limitation exists in this method, it is valuable to apply the V protein-based ELISA for differentiation of infected and vaccinated chickens.

$\mathrm{V}$ protein might also be useful as a diagnostic marker for paramyxovirus infections since the amino acid sequences of the $\mathrm{C}$ termini of $\mathrm{V}$ proteins of paramyxoviruses are highly conserved (Matsuoka et al., 1991).

\section{CONCLUSION}

Purified V protein, the non-structural protein of Newcastle disease virus (NDV) might be useful as a diagnostic marker for NDV, so that we recommend to be used as a coating antigen for an indirect ELISA or an indirect Western Blotting that could differentiate antibodies from poultry infected by NDV and poultry vaccinated with inactivated vaccine.

\section{REFERENCES}

Ashraf, A., Shah, M.S. (2014). Newcastle disease: present status and future challenges for developing countries. African J. of Microb. Res. 8(5): 411-416. http://dx.doi.org/10.5897/AJMR2013.6540

GE Healthcare Handbook: Glutathione S-transferase (GST) Gene Fusion System (2009)

https://www.gelifesciences.co.jp/catalog/pdf/DF_28962284AA_GST_Gene Fusi on System.pdf

Hernandez, R., Brown, DT. (2010) Growth and maintenance of chick embryo fibroblasts (CEF)

Curr Protoc Microbiol. $2010 \quad$ May;Appendix $4: 4 \mathrm{I}$ http://dx.doi.org/10.1002/9780471729259.mca04is17.

Lamb, RA., Parks, GD. (2007). Paramyxoviridae: The viruses and their replication. In: Fields, Virology (Knipe DM, Howley PM eds.), vol.1, (5thedn), Woltus Kluwer/Lippincott Williams, Wilkins, P. 1449-1496.

Liang, JW., Tian, FL., Lan, ZR., Huang, B., Zhuang, WZ. (2010). Selection characterization on overlapping reading frame of multiple-protein-encoding $\mathrm{P}$ gene in Newcastle disease virus. Veterinary Microbiology 144, 257-263. http://dx.doi.org/10.1080/0307945970841922210.1016/j.vetmic.2009.12.029

Matsuoka, Y., Curran, J., Pelet, T., Kolakofsky, D., Ray, R., et al. (1991). The P gene of human parainfluenza virus type 1 encodes $\mathrm{P}$ and $\mathrm{C}$ proteins but not a cysteine-rich V protein. The Journal of Virology 65, 3406-3410. http://dx.doi.org/10.1080/030794597084192220022-538X/91/063406-05\$02.00/0 Park, MS., Garcia-Sastre, A., Cros, JF., Basler, CF., Palese, P. (2003). Newcastle disease virus $\mathrm{V}$ protein is a determinant of host range restriction. The Journal of Virology $77, \quad 9522-9532$ http://dx.doi.org/10.1080/0307945970841922210.1128/JVI.77.17.9522-

9532.2003
Peeters, B., Verbruggen, P., Nelissen, F., de Leeuw, O. (2004). The P gene of Newcastle disease virus does not encode an accessory X protein. The Journal of
General
Virology
85 ,
2375-2378.

http://dx.doi.org/10.1080/0307945970841922210.1099/vir.0.80160-0

Sambrook, J., Russell, D.W. (2001) Molecular Cloning: A Laboratory Manual, 3rd edition, Vol. 1, Cold Spring Harbor Laboratory Press: New York.

Steward, M., Vipond, IB., Millar, NS., Emmerson, PT. (1993). RNA editing in Newcastle disease virus. The Journal of General Virology 74, 2539-2547. http://dx.doi.org/10.1080/0307945970841922210.1099/0022-1317-74-12-2539

Tumpey, TM., Alvarez, R., Swayne, DE., Suarez, DL. (2005). Diagnostic approach for differentiating infected from vaccinated poultry on the basis of antibodies to NS1, the nonstructural protein of influenza A virus. Journal of Clinical Microbiology 43, 676-683. http://dx.doi.org/10.1080/0307945970841922210.1128/JCM.43.2.676-683.2005 